\title{
Interação e Autismo: uso de agentes inteligentes para detectar déficits de comunicação em ambientes síncronos
}

Roberto dos Santos Rabello

Orientadora: Rosa Maria Vicari

Coorientadora: Liliana Maria Passerino

Data da defesa: $12 / 07 / 2010$

Os seres humanos dependem da interação social para desenvolver-se e evoluir, principalmente nos aspectos cognitivos. Este princípio é abordado principalmente por autores como Vigotsky (1998), que considera a interação social como o motor do desenvolvimento cognitivo humano. Em contrapartida, no caso das pessoas com autismo, conforme Hobson (1993), a sua característica principal é a limitação ou deficiência que apresenta na sua capacidade de ter um sentido da relação pessoal e de experimentar essa relação, ou, dito de outra forma, de criar um significado para a interação social e, consequentemente, participar da mesma. Essa limitação de comunicação de pessoas com autismo se caracteriza na dificuldade de utilizar, com sentido, todos os aspectos da comunicação verbal e não-verbal. Incluindo gestos, expressões faciais, linguagem corporal, ritmo e modulação da linguagem verbal, da ecolalia. A interação social, antes realizada através das relações face-aface, foi, ao longo da história, transformando-se através da interposição de inúmeras formas de mediação, entre as quais encontramos as comunicações mediadas por computador. Apesar do amplo uso do computador na educação especial, ainda são poucas as pesquisas que abordam o uso desta tecnologia na interação com pessoas com autismo, principalmente no que se refere ao seu uso como ferramenta para mediação de comunicação. Isto foi, sem dúvida, um dos motivos que levaram a pesquisar mais sobre o assunto e que acabou gerando esta pesquisa. Assim, esta pesquisa visa identificar como podemos inferir computacionalmente, a partir da análise de uma conversação online com um sujeito com autismo, os déficits de comunicação presentes nessa conversação de tal forma que possa ser oferecido algum tipo de compensação utilizando agentes inteligentes. Este mecanismo de compensação deve melhorar a comunicação e, conseqüentemente, a interação social, como pode ser percebido apenas com a utilização de um simples comunicador como o MSN. Podemos destacar os resultados da pesquisa, pois obtivemos uma efetividade grande no que diz respeito à detecção dos principais déficits conversacionais de pessoas com autismo. Dentre os déficits selecionados para detecção, encontram-se ecolalia, ausência de interação, interação reativa, ausência de saudação e inversão pronominal. É importante salientar que todos os diálogos coletados e que apresentaram déficits durante a fase inicial foram submetidos ao sistema multiagentes, comprovando a sua eficiência.

Palavras-Chave: Agentes Inteligentes. Autismo. Comunicadores Síncronos. Interação Social. 